\title{
Compositional quality of food obtained with solid state fermentation: potato and carrot
}

\section{Calidad composicional de alimentos obtenidos por fermentación en estado sólido: papa y zanahoria}
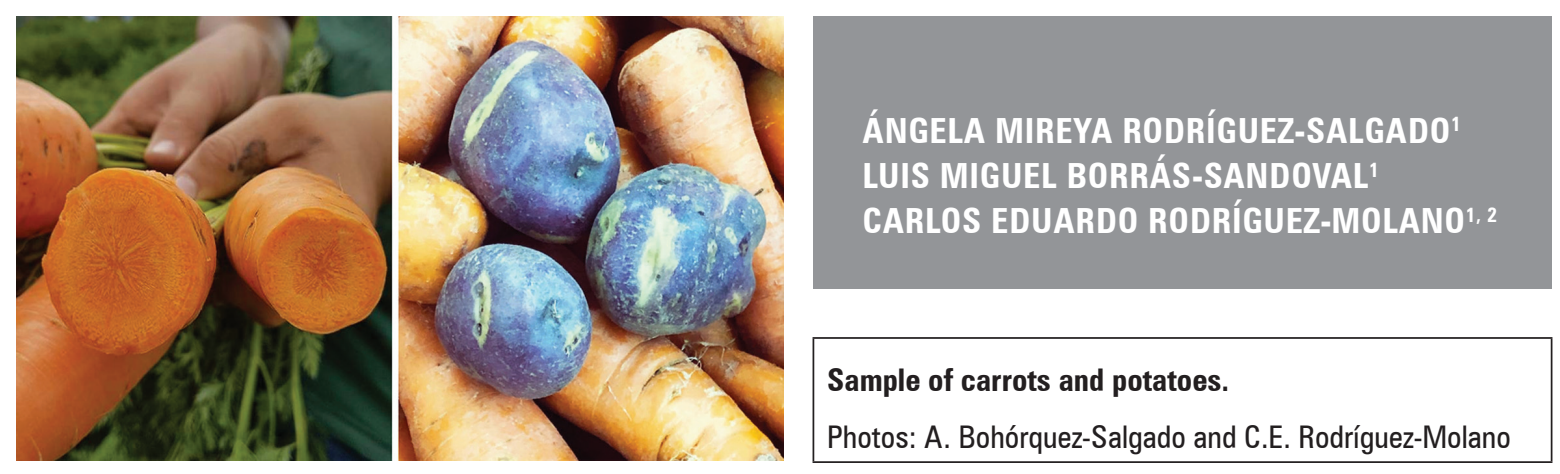

Sample of carrots and potatoes.

Photos: A. Bohórquez-Salgado and C.E. Rodríguez-Molano

\begin{abstract}
The fermentation indicators and compositional quality of food made with the solid-state fermentation of potatoes and carrots were analyzed in order to make use of foods that do not meet the requirements of consumers. Three treatments were formulated by varying the potato:carrot ratio mixed with wheat bran and corn cabbage. A microbiological analysis was performed at 0,24 and 96 hours; the $\mathrm{pH}$, crude protein (PC), ash (CZ), ethereal extract (EE), crude fiber (FC), neutral detergent fiber (FDN) and acid detergent fiber (FDA) were monitored at $0,24,48,72$ and 96 hours. Acidification was observed between sampling at 0 and 96 hours, with values ranging from 5.68 to $4.46,5.73$ to 4.46 and 5.69 to 4.33 for the treatments with the potato:carrot ratios 20:20, 25:25 and 30:30, respectively. Similarly, a reduction of dry matter $(P \leq 0.05)$ and PC increase $(P \leq 0.05)$ were observed from 20.1 to $26.7 \%, 21.1$ to $27.1 \%$ and 25.4 to $27.9 \%$, respectively for the previous ratios. No significant statistical difference was found in the variables CZ, MS, EE, FDN, FDA or FC; a significant growth of lactic acid bacteria (LAB) counts and an absence of Salmonella were evident. The proportionality in the PC increase with the potato:carrot ratios was viable with the increase of the drying material, such as wheat bran and corn cabbage.
\end{abstract}

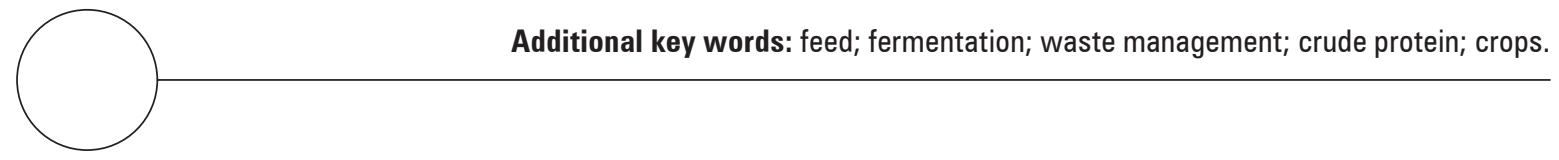

\footnotetext{
1 Universidad Pedagógica y Tecnológica de Colombia, Grupo de investigación GIBNA, Tunja (Colombia). ORCID Rodríguez-Salgado, A.M.: 0000-0003-2187-9301; ORCID Borrás-Sandoval, L.M.: 0000-0002-3284-027X; ORCID Rodríguez-Molano, C.E.: 0000-0002-0862-3478.

2 Corresponding author: carlos.rodriguez@uptc.edu.co
} 


\section{RESUMEN}

Se analizaron los indicadores fermentativos y calidad composicional de un alimento por fermentación en estado sólido de papa y zanahoria; con el fin de aprovechar alimentos que no cumplen las exigencias del consumidor final. Se formularon tres tratamientos variando las inclusiones de papa:zanahoria, en mezcla con salvado de trigo y repila de maíz. Se realizó un análisis microbiológico a las 0, 24 y 96 horas; seguimiento a pH, proteína cruda (PC), cenizas (CZ), extracto etéreo (EE), fibra cruda (FC), fibra detergente neutro (FDN) y fibra detergente ácido (FDA) a las 0, 24, 48,72 y 96 horas. Se presentó acidificación entre el muestreo 0 y 96 horas, con valores de 5,68 a 4,46; 5,73 a 4,46 y de 5,69 a 4,33 para los tratamientos con inclusiones de papa:zanahoria 20:20,25:25 y 30:30, respectivamente. De igual forma, se observó reducción de materia seca $(P \leq 0,05)$ y aumento de PC $(P \leq 0,05)$ de 20,1 a $26,7 \%, 21,1$ a $27,1 \%$ y de 25,4 a $27,9 \%$, respectivamente para las anteriores inclusiones. No se encontró diferencia estadística significativa en las variables CZ, MS, E.E, FDN, FDA y FC; se evidenció un crecimiento importante de recuentos de bacterias acido lácticas (BAL) y la ausencia de Salmonella. La proporcionalidad en los incrementos de PC con inclusiones papa:zanahoria resulta viable con el incremento del material secante como salvado de trigo y repila de maíz.

Palabras clave adicionales: pienso; fermentación; aprovechamiento de residuos; proteína cruda; hortalizas.

Received for publication: 23-10-2018 Accepted for publication: 29-03-2019

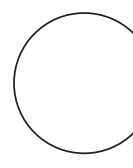

The Department of Boyaca is characterized as an agricultural territory, favoring different crops, including potatoes (S. tuberosum) and carrots (Daucus carota L.). The potato has a cultivated area of 36,146 ha, average yield of $18.9 \mathrm{t} \mathrm{ha}^{-1}$, total production of 713,592 $t$ and large quantities of post-harvest waste; this department is ranked second for potato production in Colombia (Fedepapa, 2018). On the other hand, this department is also among the main carrot producers with a cultivated area of 1,765 ha, average yield of $38.13 \mathrm{t} \mathrm{ha}^{-1}$ (Agronet, 2015) and losses of 1\% associated product deformation and alteration. The high amounts of post-harvest waste not only generate economic losses for producers but also potentially polluting agents.

Potato and carrot residues are nutritious components that can be used as animal feed with solid-state fermentation (SSF), thus avoiding possible contamination of the environment and generating a benefit to livestock production. SSF is a process that completes the carbon cycle, decomposes organic matter with fungi and bacteria that, when grown on a solid substrate, releases nutrients and energy (Peng et al., 2019).

SSF is characterized by microbial growth on a solid substrate (textured and porous), which has a low moisture content, in order to optimize the amount of protein and other nutrients contained in food that an animal will consume (Chen and Wang, 2017; Tosuner et al., 2018). In essence, it involves the use of microorganisms in order to achieve special properties in food. The growth process of the microorganisms on the substrate uses it as a source of nitrogen and nutrient salts, creating certain parameters of moisture, $\mathrm{pH}$, aeration and temperature (Costa et al., 2018).

Fonseca-López et al. (2018) pointed out that carrot is a solid substrate that provides desirable sugars for the development of the fermenting microbiota in the SSF process, obtaining 16,17 and $16.6 \%$ proteins when mixed with other materials. The objective of this research was to evaluate the nutritional and microbiological quality of food obtained with solid-state fermentation using potatoes and carrots.

\section{MATERIALS AND METHODS}

This research was carried out in the animal nutrition laboratory of the Universidad Pedagógica y Tecnológica de Colombia (Uptc), located in the city of Tunja, in the Department of Boyaca (Colombia), from April to July, 2018.

Potato and carrot crop residues from the local market of Tunja were used, which were mixed with 
drying materials such as: corn cabbage and wheat bran (by-products of grain and cereal plants from the municipality of Duitama), palm kernel high in fat (byproduct of the oil industry), 99.5\% magnesium sulfate, $38 \%$ calcium carbonate, urea with $46 \%$ nitrogen, sugar cane (Saccharum officinarum) and inoculum of Lactic Acid Bacteria (LAB).

Three treatments with different potato and carrot ratios were established. The composition was as follows: (1) 20:20 potato:carrot (20\% potato, $20 \%$ carrot); $21 \%$ wheat bran; $21 \%$ corn cabbage; $5 \%$ palm kernel; $2 \%$ urea; $0.5 \%$ magnesium sulfate; $0.5 \%$ calcium carbonate; $5 \%$ LAB inoculum and $5 \%$ sugar cane. (2) $25: 25$ potato:carrot ( $25 \%$ potato, $25 \%$ carrot); $16 \%$ wheat bran; $16 \%$ wheat cabbage; $5 \%$ palm kernel; $2 \%$ urea; $0.5 \%$ magnesium sulfate; $0.5 \%$ calcium carbonate; $5 \%$ LAB inoculum and $5 \%$ sugar cane. (3) $30: 30$ potato:carrot (30\% potato, $30 \%$ carrot); $11 \%$ wheat bran; $11 \%$ wheat cabbage; $5 \%$ palm kernel; $2 \%$ urea; $0.5 \%$ magnesium sulfate; $0.5 \%$ calcium carbonate; $5 \%$ LAB inoculum and $5 \%$ sugar cane.

The inoculum followed the methodology Borras et al. (2017): microorganisms from a culture of heterofermentative lactic acid bacteria (LAB) of medium and rapid acidification, Lactobacillus delbrueckiis ssp. bulgaricus and Streptococcus thermophilus (commercial lyophilized, Liofast Y452B, SACCO®), applied to the SSF at $48 \mathrm{~h}$ post-preparation.

1,200 g of food were prepared per treatment, divided into three repetitions. In the SSF preparation, the main raw materials, or crop waste, (potato-carrot) were washed to remove excess organic matter and avoid an over-estimate of the ash values. The materials were then crushed to a size of approximately 4 $\mathrm{mm}$, mixed manually with the rest of the ingredients until a homogeneous mixture was achieved, and finally packed in sealed polyethylene (Ziploc $($ ) bags at $25^{\circ} \mathrm{C}$ to allow the fermentation process.

$\mathrm{pH}$ monitoring was performed at $0,24,48,72$ and $96 \mathrm{~h} .5 \mathrm{~g}$ of sample were removed, and $45 \mathrm{~mL}$ of sterile distilled water were added. The preparation was stirred for 30 min on an Adams ${ }^{\circledR}$ electric stirrer, and subsequently the filtrate was obtained for measurement with an Okaton ${ }^{\circledR}$ automatic potentiometer (Oakton Instruments, Vernon Hills, IL).

The crude protein (\% PC), dry matter (\% MS), ash $(\% \mathrm{CZ})$, ethereal extract $(\mathrm{EE})$, nitrogen free extract
(\% ELN) were also determined using the Kjeldahl method, and the neutral detergent fiber (\% FDN) and acid detergent fiber (\% FDA) were determined with the Van Soest et al. (1991) at 0, 24, 48, 72 and 96 h.

A microbiological follow-up was performed at 0, 24, $96 \mathrm{~h}$ for the mesophilic aerobes (CFU/mL) (AOAC 966.23.C: 2001), total coliforms (NMP) (ICMSF NMP: 2000), total and fecal coliforms (NMP) (ICMSF NMP: 2000), Clostridium Sulfite reducing spores (CFU/mL) (ISO 15213: 2003), fungi and yeasts (CFU/mL) (ISO 7954: 1987), Salmonella (AS 5013.10: 2009), lactic acid bacteria (NTC 5034: 2002).

A completely randomized design was applied. The data were submitted to the assumptions of normality with the Shapiro-Wilk statistic and homogeneity of variance levene test. The Tukey mean comparison test with a significance level of $5 \%$ was used. The statistical package used was SPSS v 23.

\section{RESULTS AND DISCUSSION}

A decrease in $\mathrm{pH}$ was observed for the three treatments (Tab. 1); however, there was a greater decrease between 24 and $48 \mathrm{~h}$. For the measurements from 72 to $96 \mathrm{~h}$, the trend achieved stability for the $\mathrm{pH}$ levels.

Table 1. pH changes in solid state fermentation using different potato:carrot ratios as the main materials.

\begin{tabular}{|c|c|c|c|}
\hline Hour(s) & $20: 20$ & $25: 25$ & $30: 30$ \\
\hline 0 & $5.68 \pm 0.006 \mathrm{~b}$ & $5.73 \pm 0.003 \mathrm{a}$ & $5.69 \pm 0.006 \mathrm{~b}$ \\
\hline 24 & $5.49 \pm 0.012 \mathrm{a}$ & $5.36 \pm 0.012 \mathrm{~b}$ & $5.02 \pm 0.023 \mathrm{c}$ \\
\hline 48 & $4.72 \pm 0.012 \mathrm{a}$ & $4.65 \pm 0.009 \mathrm{~b}$ & $4.47 \pm 0.020 \mathrm{c}$ \\
\hline 72 & $4.62 \pm 0.019 \mathrm{a}$ & $4.52 \pm 0.012 \mathrm{~b}$ & $4.42 \pm 0.006 \mathrm{c}$ \\
\hline 96 & $4.46 \pm 0.00 \mathrm{a}$ & $4.46 \pm 0.00 \mathrm{a}$ & $4.33 \pm 0.006 \mathrm{~b}$ \\
\hline
\end{tabular}

Means followed by the same letter in the row, indicate significant difference according to the Tukey test $(P \leq 0.05)$; \pm standard error $(n=3)$.

Similar results were reported by Córdoba-Castro and Guerrero-Fajardo (2016) who pointed out that the decrease in $\mathrm{pH}$ in foods obtained with fermentation is due to the acids produced by biochemical reactions, especially lactic acid.

It is important to highlight that the $\mathrm{pH}$ values must remain in a range of 3.5 to 6.0 in order to allow an adequate growth of the microorganisms in the SSF 
process (Pandey et al., 2001; Elias et al., 2009). On the other hand, the decrease in $\mathrm{pH}$ values is related to the production of volatile fatty acids generated in the digestion of carbohydrates mediated by the microorganisms; however, lactic acid is the desired predominant acid, which is why $\mathrm{LAB}$ type microorganisms are added (Chundakkadu, 2005).

An increase in DM was observed in the 20:20 potato:carrot treatment (Tab. 2) because the inclusion of the substrate was lower compared to the other treatments.

Table 2. Dry matter changes in solid state fermentation using different potato:carrot ratios as the main materials.

\begin{tabular}{|c|c|c|c|}
\hline Hour(s) & $20: 20$ & $25: 25$ & $30: 30$ \\
\hline 0 & $58.08 \pm 0.14 \mathrm{a}$ & $50.11 \pm 0.15 \mathrm{~b}$ & $41.23 \pm 1.03 \mathrm{c}$ \\
\hline 24 & $56.74 \pm 0.10 \mathrm{a}$ & $47.08 \pm 0.92 \mathrm{~b}$ & $41.4 \pm 0.48 \mathrm{c}$ \\
\hline 48 & $55.27 \pm 0.06 \mathrm{a}$ & $47.46 \pm 0.23 \mathrm{~b}$ & $40.92 \pm 0.38 \mathrm{c}$ \\
\hline 72 & $54.70 \pm 0.20 \mathrm{a}$ & $47.06 \pm 0.38 \mathrm{~b}$ & $40.14 \pm 0.55 \mathrm{c}$ \\
\hline 96 & $54.03 \pm 0.13 \mathrm{a}$ & $47.14 \pm 0.04 \mathrm{~b}$ & $40.43 \pm 0.23 \mathrm{c}$ \\
\hline
\end{tabular}

Means followed by the same letter in the row, indicate significant difference according to the Tukey test $(P \leq 0.05) ; \pm$ standard error $(n=3)$.

The decrease in the DM\% may have been related to the processes of hydrolysis of urea, fermentation of sugars (sucrose, glucose, fructose), starches, and other carbohydrates; and on a smaller scale, the decrease was also due to the deamination of peptides and amino acids. All of these processes were mediated by the microorganisms present during metabolic processes (Brea-Maure et al., 2015). Other studies have stated that this decrease is the result of the hydrolytic action of bacterial enzymes that produce water and volatile compounds (Carrasco et al., 2015; Rodríguez et al., 2001). Therefore, the decrease in dry matter is due to a fermentation process of carbohydrates during SSF, causing a significant increase in the concentration of volatile fatty acids (VFA) and a decrease in pH (Castillo, 2011).

The $\mathrm{CZ}$ values increased for the three treatments (Tab. 3), ranging from 5.5 to 7.09 , evidencing the greatest increase in the treatment 30:30. Ash contains salts and oxides of different chemical elements, mainly minerals (Cárdenas et al., 2008).
Table 3. Ash changes (\% CZ) in solid state fermentation using different potato:carrot ratios as the main materials.

\begin{tabular}{|c|c|c|c|}
\hline Hour(s) & $20: 20$ & $25: 25$ & $30: 30$ \\
\hline 0 & $5.57 \pm 0.09 \mathrm{a}$ & $5.79 \pm 0.04 \mathrm{a}$ & $5.50 \pm 0.42 \mathrm{a}$ \\
\hline 24 & $6.10 \pm 0.02 \mathrm{~b}$ & $6.07 \pm 0.00 \mathrm{~b}$ & $6.69 \pm 0.09 \mathrm{a}$ \\
\hline 48 & $6.30 \pm 0.03 \mathrm{c}$ & $6.60 \pm 0.03 \mathrm{~b}$ & $7.01 \pm 0.06 \mathrm{a}$ \\
\hline 72 & $6.11 \pm 0.01 \mathrm{c}$ & $6.67 \pm 0.01 \mathrm{~b}$ & $6.96 \pm 0.11 \mathrm{a}$ \\
\hline 96 & $6.31 \pm 0.07 \mathrm{~b}$ & $6.61 \pm 0.06 \mathrm{~b}$ & $7.09 \pm 0.11 \mathrm{a}$ \\
\hline
\end{tabular}

Means followed by the same letter in the row, indicate significant difference according to the Tukey test $(P \leq 0.05) ; \pm$ standard error $(n=3)$.

This increase in the ash values was also reported by Pérez (1996) who, when using fermentation on Pennisetum americanum (L.) Leeke (pearl millet), observed that the ash value went from 1.6 to $2.1 \%$ in $72 \mathrm{~h}$ as a result of cellular metabolism. In another study, when SSF was carried out on the flour of the breadfruit tree, an increase in the ash values of 7.87 to $8.52 \%$ was evident (Brea et al., 2014). In studies carried out with different potato:carrots ratios and energy sources (molasses, glycerol), an increase in ash percentage values has been observed, obtaining results that ranged between $7.2 \%$ at $24 \mathrm{~h}$ (Huertas et al., 2016 ) and 5 to $7 \%$ of CZ (Cala et al., 2015).

Ramos (2006) pointed out that ash may be related to the energy source used in the process. However, Escudero (2012) stated that, in fermentation processes, decreases in ash levels can be observed because the microorganisms require a large amount of nutrients, among them minerals, in their biochemical processes. This is why it is important to enrich the solid matrix of the substrate with minerals and thus improve the carbon:nitrogen ratio and provide other nutritional elements required by the microorganisms.

Ash is an indicator of the mineral content of a food; however, if the values are greater than 15\%, improper handling can be suspected because some kind of contamination could have occurred, such as contact with dirt (Argamentaria et al., 1997). According to the results obtained in the present study, no value exceeded this level, so it is evident that there was no contamination.

An increase in PC was evidenced for treatments from 0 to $96 \mathrm{~h}$ (Tab. 4). The food did not show significant 
statistical differences. However, $48 \mathrm{~h}$ showed an increase in the PC levels with the increasing concentrations of carrot-potatoes.

\section{Table 4. Crude protein changes in solid state fermentation using different potato:carrot ratios as the main materials.}

\begin{tabular}{|c|c|c|c|}
\hline Hour(s) & $20: 20$ & $25: 25$ & $30: 30$ \\
\hline 0 & $20.1 \pm 2.89 \mathrm{a}$ & $21.1 \pm 2.99 \mathrm{a}$ & $25.4 \pm 1.66 \mathrm{a}$ \\
\hline 24 & $25.7 \pm 0.26 \mathrm{a}$ & $27.4 \pm 0.25 \mathrm{a}$ & $27.0 \pm 1.28 \mathrm{a}$ \\
\hline 48 & $26.1 \pm 0.26 \mathrm{c}$ & $27.8 \pm 0.68 \mathrm{~b}$ & $30.2 \pm 0.44 \mathrm{a}$ \\
\hline 72 & $26.7 \pm 0.48 \mathrm{a}$ & $29.1 \pm 0.20 \mathrm{a}$ & $25.8 \pm 2.48 \mathrm{a}$ \\
\hline 96 & $26.7 \pm 0.48 \mathrm{a}$ & $27.1 \pm 0.22 \mathrm{a}$ & $27.9 \pm 3.66 \mathrm{a}$ \\
\hline
\end{tabular}

Means followed by the same letter in the row, indicate significant difference according to the Tukey test $(P \leq 0.05) ; \pm$ standard error $(n=3)$.

In a previous study by Cala et al. (2015), there was an increase in the PC in the different sampling times, resulting in protein of 20.19 and $21.03 \%$ at 24 and 48 $\mathrm{h}$, respectively, data that match the data obtained in this study (Tab. 4).

Elias et al. (2009) reported that an increase in protein levels was due to a synchronization between nonprotein nitrogen contained in urea and carbohydrates added to the SSF, allowing the microorganisms to incorporate nitrogen and available carbon into their protoplast and forming amino acid chains and generating the synthesis of microbial proteins. When inoculating the microorganisms, a greater retention of ammonia was observed as a result of the lower $\mathrm{pH}$, which increased the PC content. Additionally, when there is an increase in the PC values, if some compounds are incorporated that are sources of phosphate, nitrogen and microelements such as: calcium, iron, magnesium, manganese, copper, etc. (Ramos, 2005), the increase in PC is a result of inoculation with microorganisms, calcium carbonate and magnesium sulfate. Finally, an increase in PC values in fermentation processes was reported by Cárdenas et al. (2008); Rodríguez et al. (2001) and Fonseca-López et al. (2018), who obtained increases in PC from 11.5 to $16.3 \%, 10.1$ to $13.7 \%$ and 4.34 to $19 \%$, respectively.

The SSF was stable for the ethereal extract (EE) (Tab. 5). For the measurement time (48 h), the 20:20 and 25:25 potato:carrot treatments showed levels of $6.7 \% \mathrm{EE}$ and $6.3 \%$ for the $30: 30$ potato:carrot treatment; there was no significant statistical difference
$(P>0.05)$. This variable corresponds to the group of nutrients called crude fat or lipids, where fat-soluble vitamins are also found.

\section{Table 5. Ethereal extract changes in solid state fermenta- tion using different potato:carrot ratios as the main materials.}

\begin{tabular}{|c|c|c|c|}
\hline Hour(s) & $20: 20$ & $25: 25$ & $30: 30$ \\
\hline 0 & $6.7 \pm 0.07 \mathrm{a}$ & $6.4 \pm 0.27 \mathrm{ab}$ & $5.6 \pm 0.18 \mathrm{~b}$ \\
\hline 24 & $6.0 \pm 0.52 \mathrm{a}$ & $6.1 \pm 0.07 \mathrm{a}$ & $5.6 \pm 0.36 \mathrm{a}$ \\
\hline 48 & $6.7 \pm 0.07 \mathrm{a}$ & $6.7 \pm 0.50 \mathrm{a}$ & $6.3 \pm 0.09 \mathrm{a}$ \\
\hline 72 & $6.4 \pm 0.03 \mathrm{a}$ & $6.4 \pm 0.27 \mathrm{a}$ & $6.2 \pm 0.79 \mathrm{a}$ \\
\hline 96 & $6.4 \pm 0.35 \mathrm{a}$ & $7.2 \pm 0.35 \mathrm{a}$ & $6.5 \pm 0.33 \mathrm{a}$ \\
\hline
\end{tabular}

Means followed by the same letter in the row, indicate significant difference according to the Tukey test $(P \leq 0.05) ; \pm$ standard error $(n=3)$.

The fiber composition (FDN and FDA) is used for the prediction of food quality since it influences the consumption of dry matter, digestibility and energy value. The FDN, FDA and FC values showed no statistical differences $(P>0.05)$ between the treatments (Tab. 6).

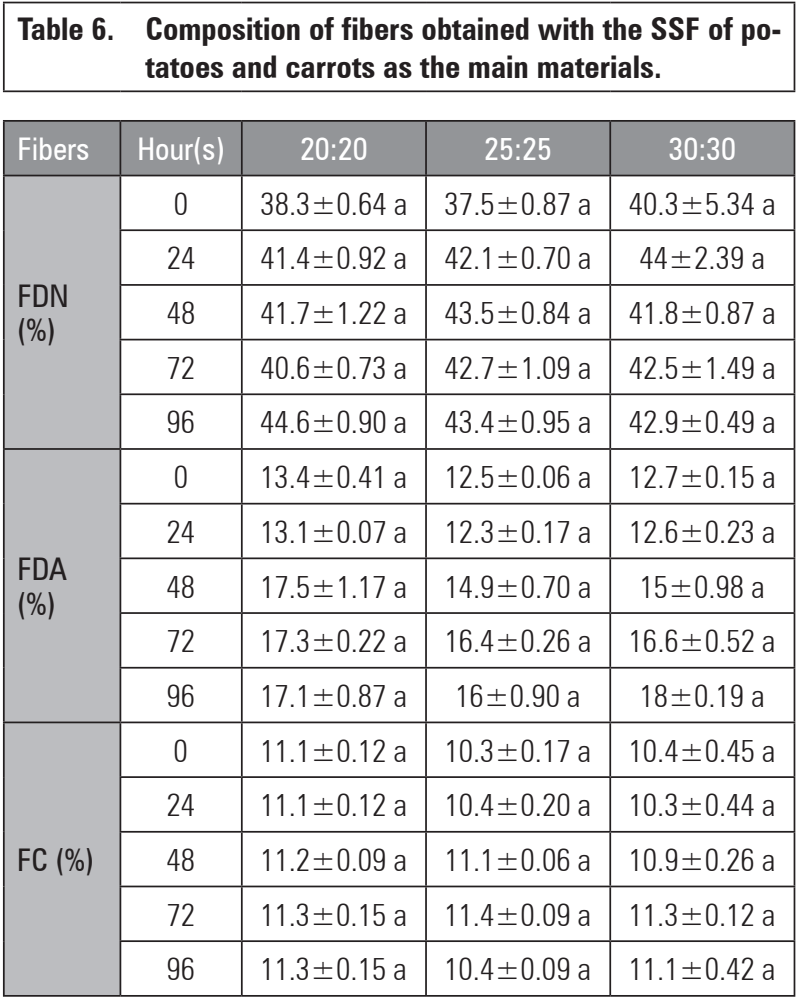

Means followed by the same letter in the row, indicate significant difference according to the Tukey test $(P \leq 0.05) ; \pm$ standard error $(n=3)$. 
However, Polished et al. (2016) reported a decrease in HR levels in the evaluation of SSF using pear harvest residues (Pyrus communis) at 24, 48 and $72 \mathrm{~h}$ of fermentation. Ruiz et al. (2009) observed variations in FDN and FDA in silage processes, which are related to changes in soluble sugars. On the other hand, Herrera et al. (2014) argued that, during the fermentation of cacti, the contents of FDN and FDA were reduced with the presence of yeasts at $96 \mathrm{~h}$ of the fermentation process.

Cruz-Calvo and González (2000) pointed out that fiber is a set of components that have low digestibility and promote rumination and ruminal balance, that is, the main component in most ruminant production systems.

\section{Table 7. Microbiological analysis of potato and carrot fer-} mentation as the main SSF materials.

\begin{tabular}{|c|c|c|c|c|}
\hline Microorganism & Inclusion & $\begin{array}{c}0 \\
\text { hour }\end{array}$ & $\begin{array}{c}24 \\
\text { hours }\end{array}$ & $\begin{array}{c}96 \\
\text { hours }\end{array}$ \\
\hline \multirow{3}{*}{$\begin{array}{l}\text { Mesophilic aerobes } \\
\text { (CFU/g) }\end{array}$} & $20: 20$ & & $38 \cdot 10^{6}$ & $41 \cdot 10^{5}$ \\
\hline & $25: 25$ & $10 \cdot 10^{6}$ & $79 \cdot 10^{6}$ & $11 \cdot 10^{5}$ \\
\hline & $30: 30$ & & $15 \cdot 10^{6}$ & $21 \cdot 10^{6}$ \\
\hline \multirow{3}{*}{$\begin{array}{l}\text { Total coliforms } \\
\text { (NMP) }\end{array}$} & $20: 20$ & & $>1100$ & $<3$ \\
\hline & $25: 25$ & $>1100$ & 1100 & $<3$ \\
\hline & $30: 30$ & & $>1100$ & $<3$ \\
\hline \multirow{3}{*}{$\begin{array}{l}\text { Fecal coliforms } \\
\text { (NMP) }\end{array}$} & $20: 20$ & & $<3$ & $<3$ \\
\hline & $25: 25$ & 3.6 & $<3$ & $<3$ \\
\hline & $30: 30$ & & 9.1 & $<3$ \\
\hline \multirow{3}{*}{$\begin{array}{l}\text { Sulphite reducing } \\
\text { Clostridium spores } \\
\text { (CFU/g) }\end{array}$} & $20: 20$ & & & \\
\hline & $25: 25$ & * & $<10$ & $<10$ \\
\hline & $30: 30$ & & & \\
\hline \multirow{3}{*}{$\begin{array}{l}\text { Fungi } \\
\text { (CFU/g) }\end{array}$} & $20: 20$ & & $10 \cdot 10^{2}$ & 10 \\
\hline & $25: 25$ & $<10$ & $20 \cdot 10^{3}$ & $<10$ \\
\hline & $30: 30$ & & 10 & 20 \\
\hline \multirow{3}{*}{$\begin{array}{l}\text { Yeasts } \\
\text { (CFU/g) }\end{array}$} & $20: 20$ & & $51 \cdot 10^{4}$ & $32 \cdot 10^{4}$ \\
\hline & $25: 25$ & $32 \cdot 10^{4}$ & $80 \cdot 10^{4}$ & $30 \cdot 10^{4}$ \\
\hline & $30: 30$ & & $49 \cdot 10^{4}$ & $58 \cdot 10^{4}$ \\
\hline \multirow{3}{*}{ Salmonella } & $20: 20$ & & & \\
\hline & $25: 25$ & * & * & * \\
\hline & $30: 30$ & & & \\
\hline \multirow{3}{*}{$\begin{array}{l}\text { Lactic acid bacteria } \\
\text { (CFU/g) }\end{array}$} & $20: 20$ & & $32 \cdot 10^{6}$ & $52 \cdot 10^{6}$ \\
\hline & $25: 25$ & $10 \cdot 10^{6}$ & $79 \cdot 10^{6}$ & $78 \cdot 10^{6}$ \\
\hline & $30: 30$ & & $15 \cdot 10^{6}$ & $58 \cdot 10^{6}$ \\
\hline
\end{tabular}

${ }^{*}$ Absence $25 \mathrm{~g}$
In all the treatments, a significant $\mathrm{LAB}$ growth count (Tab. 7) was evidenced as a sign of the effectiveness of the inoculum used, especially with the 25:25 potato:carrot ratio at $96 \mathrm{~h}$ of fermentation $\left(78 \cdot 10^{6}\right)$. Likewise, the absence of pathogens such as Salmonella and Clostridium and decreases in coliform counts were observed, presumably as a result of the efficiency of fermentation. It is important to note that there is no standard to compare and evaluate these results, but the figures suggest that the product is safe for animal feed.

In previous studies, LAB strains have been isolated and characterized from native microbial preparations made from agroindustrial residues, such as whey, bovine manure and ruminal contents, designed as biological inoculants for postharvest organic waste silage processes and proposed for studies on other crop residues with these inoculants (Díaz et al., 2014). In another study, where they evaluated the quality of a silage made with potato waste and inoculated with BAL, an increase in the amount of protein, reduction of fiber and decrease in digestibility in animals were observed (Nkosi et al., 2015).

\section{CONCLUSIONS}

Solid state fermentation is a process characterized by microbial growth on a solid substrate in order to optimize the amount of protein and other nutrients contained in a food when there is a favorable medium. The use of potato and carrot ratios of up to $30: 30(\mathrm{p} / \mathrm{p})$ in the preparation of SSF foods allows for a proper decrease in the $\mathrm{pH}$ levels in the food, which is indicative of a good fermentation process and is related to the increase in raw protein levels in the food and stability of other nutrients.

The use of potatoes and carrots in solid-state fermentation processes is feasible as a strategy in animal feed since they can be mixed with other materials because of the fermentative capacity of efficient microorganisms, obtaining $30.2 \%$ proteins at $48 \mathrm{~h}$, along with the absence of pathogens such as Salmonella and Clostridium and a decrease in coliform counts.

The Department of Boyaca is characterized as an agricultural territory, with notable potato and carrot crops occupying the largest cultivated area and total production, generating large quantities of good quality post-harvest waste that has significant nutritional components for use in animal feed. These residues are 
significant since they constitute a strategy of animal nutrition through fermented preparations that include efficient microorganisms, benefiting livestock production systems.

\section{ACKNOWLEDGMENTS}

The authors are thankful for the support of the Grupo de Investigacion en Bioquimica y Nutricion Animal GIBNA of the Universidad Pedagogica y Tecnologica de Colombia, Colciencias and the Gobernación de Boyaca.

Conflict of interests: this manuscript was prepared and reviewed with the participation of the authors, who declare that they have no conflicts of interest that place the validity of the results presented herein at risk.

\section{BIBLIOGRAPHIC REFERENCES}

Agronet. 2015. Zanahoria, resultado de las evaluaciones agropecuarias municipales. In: http://www.agronet. gov.co/Documents/Zanahoria\%20-\%20A\%-C3\%B1o\%202015.pdf; consulted: october, 2018.

AOAC, Association of Official Analytical Chemists. 2005. Official methods and analysis. $17^{\text {th }} \mathrm{ed}$. Association of Official Analytical Chemists. Arlington, VA.

Argamentería, G.A., B. De La Roza, A. Martínez, L. Sánchez, and A. Martínez. 1997. El ensilado en Asturias. Centro de Investigación Aplicada y Tecnología Agroalimentaria (CIATA), Gijon, Spain.

Borras, L.M., C.E. Rodríguez, and A.M. Rodríguez 2017. Inclusión de carbonato de calcio $\left(\mathrm{CaCO}_{3}\right)$ en la cinética de fermentación en estado sólido de residuos de poscosecha de Solanum tuberosum. Rev. Colomb. Cienc. Hortic. 11(1), 143-150. Doi: 10.17584/rcch.2017v11i1.6145

Brea-Maure, O., A. Elías-Iglesias, A. Ortiz-Milán, W. Motta-Ferreira, and S. Hechavarría-Riviaux. 2015. Efecto de la urea y del tiempo en la fermentación en estado sólido de la harina de frutos del árbol del pan (Artocarpus altilis). Cienc. Agric. 12(2), 91-101. Doi: 10.19053/01228420.4395

Brea, O., A. Ortiz, A. Elías, F. Herrera, and W. Motta. 2014. Utilización de la harina de frutos del árbol del pan (Artocarpus altilis), fermentada en estado sólido, en dietas destinadas a cerdos en preceba. Rev. Cubana Cienc. Agric. 48(4), 391-398.

Cala, D., S. Charari, A.M. Rodríguez, and G.F. Saavedra. 2015. Evaluación del efecto de un alimento a base de fermentación en estado sólido (FES) de papa (Solanum tuberosum) y zanahoria (Daucus careta L.) sobre los parámetros productivos en gallinas ponedoras. Undergraduate thesis. Facultad de Medicina Veterinaria y Zootecnia, Universidad Pedagógica y Tecnológica de Colombia, Tunja, Colombia.

Cárdenas, J.R., E.M. Aranda, D. Hernández, L. Lagunes, J.A. Ramos, and S. Salgado. 2008. Obtención de un alimento fermentado en estado sólido a partir del bagacillo de retorno, pulido de arroz e inóculos. Su utilización en la alimentación animal. Rev. Cubana Cienc. Agric. 42(2), 173-176.

Carrasco, E., A. Elías, E. Valiño, Z. Rodríguez, and I. Febles. 1996. Influencia del nivel de excreta vacuna en la fermentación en estado sólido de la caña de azúcar. Rev. Cubana Cienc. Agric. 30(2), 175-180.

Castillo, Y., O. Ruiz, C. Angulo, C. Rodríguez, A. Elias, and O. La O. 2011. Inclusión de residuos de panadería en algunos metabolitos e indicadores bromatológicos de la fermentación en estado sólido del bagazo de manzana. Rev. Cubana Cienc. Agric. 45(2), 141-144.

Chen, H. and L. Wang. 2017. Enzymatic hydrolysis of pretreated biomass. pp. 65-99. In: Technologies for biochemical conversion of biomass. Academic Press, London, UK. Doi: 10.1016/B978-0-12-802417-1.00004-1

Chundakkadu, K. 2005. Solid-state fermentation systems-an overview. Crit. Rev. Biotechnol. 25(1-2), 1-30. Doi: 10.1080/07388550590925383

Córdoba-Castro, N.M. and J.E. Guerrero-Fajardo. 2016. Characterization of the traditional coffee fermentation processes in Nariño. Rev. Bio. Agro. 14(2), 75-83. Doi: 10.18684/BSAA(14)75-83

Costa, J.A., H. Treichel, V. Kumar, and A. Pandey. 2018. Advances in solid-state fermentation. pp. 1-17. In: Pandey, A., C. Larroche, and C.R. Soccol (eds.). Current developments in biotechnology and bioengineering: current advances in solid-state fermentation. Elsevier, Amsterdam. Doi: 10.1016/B978-0-444-63990-5.00001-3

Cruz-Calvo, M.M. and J.S. González. 2000. La fibra en la alimentación del ganado lechero. Nutrición Anim. Trop. 6(1), 39-74.

Díaz, B., A. Elías, and E. Valiño. 2014. Consorcios microbianos con actividad ácido-láctica promisoria aislados desde inoculantes bacterianos nativos para ensilajes. Cienc. Agric. 11(1), 17-25. Doi: 10.19053/01228420.3484

Elías, A., L. Aguilera, Y. Rodríguez, and F. Herrera. 2009. Inclusión de niveles de harina de granos de Canavalia ensiformis en la fermentación de la caña de azúcar en estado sólido (Sacchacanavalia). Rev. Cubana Cienc. Agric. 43(1), 51-54.

Escudero-De-Fonseca, A. and C.A. Arias-Villamizar. 2012. Los microorganismos en los abonos orgánicos a partir de podas en la Universidad del Norte, Colombia. Rev. Int. Contam. Ambient. 28, 69-77.

Fedepapa, Federación Colombiana de Productores de Papa. 2018. Boletín Mensual Regional 2(2), May. 
Fonseca-López, D., G. Saavedra-Montañéz, and C.E. Rodríguez-Molano. 2018. Elaboración de un alimento para ganado bovino a base de zanahoria (Daucus carota L.) mediante fermentación en estado sólido como una alternativa ecoeficiente. Rev. Colomb. Cienc. Hortic. 12(1), 175-182. Doi: 10.17584/rcch.2018v12i1.7416

Herrera-Torres, E., M. Murillo, L. Berumen, J. Páez, and G. Villarreal. 2014. Efecto de Sacharomyces cerevisiae y Kluyveromices marxianus durante el tiempo de fermentación en la calidad nutritiva del nopal forrajero. Ecosist. Recur. Agropec. 1(1), 33-40.

Huertas, T., G.F. Saavedra, and A. Rodríguez. 2016. Evaluación del efecto del glicerol en un proceso de fermentación en estado sólido (FES) sobre la calidad composicional y microbiológica en una dieta para ovinos. Undergraduate thesis. Facultad de Medicina Veterinaria y Zootecnia, Universidad Pedagógica y Tecnológica de Colombia, Tunja, Colombia.

Nkosi, B., R. Meeskeb, T. Langaa, M. Motianga, T. Mutavhatsindia, R. Thomasa, I. Groenewaldc, and J. Baloyid. 2015. The influence of ensiling potato hash waste withenzyme/bacterial inoculant mixtures on the fermentation characteristics, aerobic stability and nutrient digestion of their resultant silages by rams. Small Rumin. Res. 127, 28-35. Doi: 10.1016/j. smallrumres.2015.04.013

Pandey, A., C.R. Soccol, J.A. Rodríguez-Leon, and P. Nigam. 2001. Solid-state fermentation in biotechnology: fundamentals and applications. Asiatech Publishers, New Delhi.

Peng, R., Z. He, T. Gou, J. Du, and H. Li. 2019. Detection of parameters in solid state fermentation of Monascus by near infrared spectroscopy. Infrared Phys. Techn. 96, 244-250. Doi: 10.1016/j.infrared.2018.11.030

Pérez, L.M. 1996. Fermentación en estado sólido del mijo de perla (Pennisetum americanum (L.) Leeke) por Rhizopus oligosporus para la obtención de un producto rico en proteína. MSc thesis. Universidad Autónoma de Nueva León, Monterey, Mexico.

Pulido, N.J., L.M. Borrás, and C.E. Rodriguez. 2016. Elaboración de un alimento energético-proteico para animales, basado en residuos de cosecha de pera (Pyrus communis). Cienc. Tecnol. Agropecu. 17(1), 7-16. Doi: 10.21930/rcta.vol17_num1_art:455

Ramos, J.A. 2005. Obtención de un concentrado energético proteico por fermentación en estado sólido de la caña de azúcar para bovinos en ceba. $\mathrm{PhD}$ thesis. Instituto de Ciencia Animal, Universidad Agraria de la Habana, La Habana.

Ramos, J., A. Elias, and F. Herrera. 2006. Procesos para la producción de un alimento energético - proteico para animale. Efecto de cuatro fuentes energéticas en la fermentación en estado sólido (FES) de la caña de azúcar. Rev. Cubana Cienc. Agric. 40(1), 51-58.

Rodríguez, Z., A. Elías, R. Boucourt, and O. Núñez. 2001. Efectos de los niveles de nitrógeno ureico en la síntesis proteica durante la fermentación de mezclas de caña (Saccharum officinarum) y boniato (Ipomea batata Lam). Rev. Cubana Cienc. Agric. 35(1), 29-36.

Ruiz, B.O., Y. Castillo, A. Anchondo, C. Rodríguez, R. Beltrán, O. La, and J. Payán. 2009. Efectos de enzimas e inoculantes sobre la composición del ensilaje de maíz. Arch. Zootec. 58(222), 163-172. Doi: 10.4321/ S0004-05922009000200001

Tosuner, Z.V., G.G. Taylan, and S. Özmıhç1. 2018. Effects of rice husk particle size on biohydrogen production under solid state fermentation. Int. J. Hydrogen Energy 44(34), 18785-18791. Doi: 10.1016/j. ijhydene.2018.10.230

Van Soest, P.J., J.B. Robertson, and B.A. Lewis. 1991. Methods for dietary fiber, neutral detergent fiber, and nons-tarch polysaccharides in relation to animal nutrition. J. Dairy Sci. 74(1), 3583-3597. Doi: 10.3168/ jds.S0022-0302(91)78551-2 